\title{
PENGARUH KONSENTRASI STARTER TERHADAP KADAR ALKOHOL, pH, DAN TOTAL ASAM TERTITRASI (TAT) WHEY KEFIR
}

\author{
The Effect of Starter Concentration on Alcohol, pH, and Total Titrated Acids (TTA) \\ in Whey Kefir
}

\author{
Anis Usfah Prastujati, Mustofa Hilmi, M. Habbib Khirzin \\ Program Studi Teknologi Pengolahan Hasil Ternak, Politeknik Negeri Banyuwangi \\ Email: anis.usfah@poliwangi.ac.id
}

\begin{abstract}
INTISARI
Whey merupakan cairan yang dihasilkan dari pemisahan curd (keju) dimana pemanfaatannya masih sangat kurang sehingga dapat menyebabkan pencemaran lingkungan. Tujuan dari penelitian ini adalah untuk mengetahui pengaruh konsentrasi starter terhadap kadar alkohol, $\mathrm{pH}$, dan total asam tertitrasi pada whey kefir. Whey yang telah dipasteurisasi ditambahkan starter dengan konsentrasi 5, 7, dan 9\% (w/v) kemudian diinkubasi pada suhu $20^{\circ} \mathrm{C}$ selama 24 jam. Metode penelitian yang digunakan adalah Rancangan Acak Lengkap (RAL) dengan 3 perlakuan dan 3 ulangan. Perlakuan yang digunakan yaitu susu sapi dengan starter 5\% sebagai kontrol (T0), whey dengan starter 5\% (T1), whey dengan starter 7\% (T2), dan whey dengan starter 9\% (T3). Data dianalisis menggunakan Analysis of Variance (ANOVA) dan dilanjutkan dengan uji Duncan Multiple Range Test (DMRT). Hasil penelitian menunjukkan bahwa semakin meningkat konsentrasi starter maka semakin tinggi kadar alkohol dan cenderung meningkatkan nilai total asam tertitrasi (TAT).
\end{abstract}

Kata kunci: Kadar Alkohol, Kefir, pH, Total Asam Tertitrasi, Whey

\begin{abstract}
Whey is a liquid produced from the separation of curd that its utilization is still very limited, so it can cause environmental pollution. The purpose of this study was to determine the effect of starter concentration on alcohol, $\mathrm{pH}$, and total titrated acids in whey kefir. Pasteurized whey was added starter with concentration of 5,7 , and $9 \%(\mathrm{w} / \mathrm{v})$ then incubated at $20^{\circ} \mathrm{C}$ for 24 hours. The research method used was Completely Randomized Design (CRD) with 3 treatments and 3 replications. The treatment used was cow milk added 5\% starter as control (T0), whey added starter 5\% (T1), whey added starter 7\% (T2), and whey added starter 9\% (T3). The data were analyzed using Analysis of Variance (ANOVA) and continued by Duncan Multiple Range Test (DMRT). The results showed that the higher starter concentration, the higher the alcohol content and tend to increase the total value of titrated acids (TTA).
\end{abstract}

Keywords: Alcohol, Kefir, pH, Total Titrated Acid, Whey

\section{PENDAHULUAN}

CV Margo Utomo merupakan perusahaan yang memproduksi keju di Kabupaten Banyuwangi. Limbah whey dari perusahaan diketahui hanya dimanfaatkan untuk minuman bagi anak sapi. Whey mengandung nutrisi yang tinggi dan memiliki manfaat untuk kesehatan, diantaranya mengontrol metabolisme tubuh, probiotik, antitumor bagi hewan, dan antibakteri (Farnworth, 2003). Oleh karena itu, pemanfaatan whey sebagai minuman fermentasi dalam bentuk whey kefir perlu 
untuk diteliti sebagai minuman fungsional. Whey didefinisikan sebagai serum atau bagian air dari susu yang tersisa setelah pemisahan curd (keju) dan merupakan hasil koagulasi protein susu dengan asam dan enzim proteolitik (Usmiati, 2007). Satu kilogram keju yang diproduksi akan menghasilkan whey sebanyak 8 sampai 10 liter (Farnworth, 2003).

Whey di Indonesia secara umum kurang dimanfaatkan dengan baik sehingga mencemari lingkungan. Whey keju memilki kandungan Biochemical Oxygen Demand (BOD) dan Chemical Oxygen Demand (COD) yang tidak memenuhi batas aman yang diperbolehkan, yaitu $50.000 \mathrm{mg} / \mathrm{L}$ (BOD) dan kadar COD sebanyak 80.000 mg/L (Guimaraes et al., 2010). Pencemaran lingkungan dapat dikurangi dengan cara memanfaatkan whey sebagai bahan dasar dalam pembuatan minuman fungsional probiotik seperti yoghurt maupun kefir. Whey kefir merupakan inovasi terbaru olahan whey yang difermentasi oleh sejumlah mikroba yaitu bakteri penghasil asam laktat (BAL), bakteri penghasil asam asetat, dan yeast (Winarno et al., 2007). Beberapa penelitian melaporkan bahwa whey kefir memiliki banyak manfaat seperti memperlancar buang air besar, mengurangi resiko konstipasi, sebagai minuman probiotik, antioksidan, penurun gula darah, penurun kadar kolesterol, dan dapat mengobati maag (Guimaraes et al., 2010).

Penelitian ini bertujuan untuk mengetahui pengaruh konsentrasi starter yang terhadap kandungan alkohol, nilai $\mathrm{pH}$, dan total asam tertitrasi whey kefir.

\section{MATERI DAN METODE}

\section{Produksi Whey Kefir}

Produksi whey kefir dilakukan berdasarkan modifikasi metode Londero et al. (2010). Whey segar disaring menggunakan kain saring kemudian filtratnya dipasteurisasi pada suhu 70 sampai $75^{\circ} \mathrm{C}$ selama kurang lebih 15 menit, lalu didiamkan hingga mencapai suhu $40^{\circ} \mathrm{C}$. Selanjutnya biji kefir (starter kombinasi yang terdiri dari BAL, yeast, dan kapang) diinokulasi ke dalam whey dengan konsentrasi sesuai perlakuan, yaitu: 5 , 7, dan 9\% (w/v), lalu diinkubasi selama 24 jam dengan temperatur $20^{\circ} \mathrm{C}$.

\section{Analisis Kadar Alkohol}

Kadar alkohol diuji menggunakan alkohol meter berdasarkan metode Satria dan Wildan (2013). Sampel dimasukkan ke dalam gelas ukur kapasitas $100 \mathrm{ml}$ lalu didinginkan pada suhu $20^{\circ} \mathrm{C}$. Alkohol meter dimasukan ke dalam gelas ukur lalu dicatat hasil pengukurannya.

\section{Analisis pH}

Nilai $\mathrm{pH}$ whey kefir dianalisis menggunakan $\mathrm{pH}$ meter. Sebelum melakukan pengujian $\mathrm{pH}$, alat $\mathrm{pH}$ meter distandarisasi dengan menggunakan buffer $\mathrm{pH} 4$, lalu dibilas dengan aquades, dilanjutkan dengan standard buffer pH 7. Sampel yang akan diamati dimasukan ke dalam gelas beaker $100 \mathrm{ml}$, kemudian $\mathrm{pH}$ meter dicelupkan ke dalam sampel hingga $\mathrm{pH}$ meter menunjukan angka yang stabil. 


\section{Analisis Total Asam Tertitrasi (TAT)}

Analisis TAT dilakukan berdasarkan SNI (2009). Sampel sebanyak 2 g dimasukan ke dalam erlenmeyer lalu ditambahkan indikator phenolphthalein 1\% dalam alkohol 70\%. Selanjutnya sampel dititrasi dengan $\mathrm{NaOH} 0,1$ $\mathrm{N}$ hingga berwarna merah muda. Nilai TAT dihitung dengan rumus:

FP x ml titrasi $\mathrm{NaOH} \times \mathrm{N} \mathrm{NaOH} \times \mathrm{BM}(30) \times 100 \%$ W sampel

Keterangan:

$\mathrm{FP}=$ faktor pengenceran

$\mathrm{N}=$ normalitas

$\mathrm{BM}=$ berat molekul asam laktat (30)

$\mathrm{W}=$ berat sampel $(\mathrm{g})$

\section{Analisis Data}

Penelitian ini menggunakan Rancangan Acak Lengkap (RAL) dengan 3 perlakuan dan 3 ulangan. Perlakuan yang digunakan yaitu susu sapi dengan starter 5\% sebagai kontrol (T0), whey dengan starter 5\% (T1), whey dengan starter 7\% (T2), dan whey dengan starter 9\% (T3). Data dianalisis menggunakan Analysis of Variance (ANOVA) dan dilanjutkan dengan uji Duncan Multiple Range Test (DMRT).

\section{HASIL DAN PEMBAHASAN}

\section{Kandungan Nutrisi Whey}

Whey merupakan hasil samping dari pengolahan keju yang masih memiliki kandungan gizi yang tinggi (Madureira et al., 2007). Kandungan nutrisi whey dipengaruhi oleh teknologi produksi, metode koagulasi, dan kualitas susu. Keju hard cheese menghasilkan whey dengan kandungan air yang tinggi karena dalam proses pembuatannya terdapat tahapan pengepresan (Handayani, 2004). Whey yang dihasilkan dari proses pasteurisasi susu yang lama cenderung memiliki kandungan nutrisi rendah karena nutrien banyak yang rusak (Larasati et al., 2016). Kualitas whey dipengaruhi oleh faktor lain diantaranya pemberian pakan ternak sebelum diperah atau perawatan dan pemberian pakan saat laktasi. Pakan dengan nutrisi tinggi mempengaruhi kandungan gizi whey keju yang dihasilkan (Laryska dan Nurhajati, 2013). Perbandingan kandungan nutrisi susu sapi segar dan whey keju disajikan pada Tabel 1.

Tabel 1. Hasil Uji Kandungan Nutrisi Susu Sapi dan Whey Keju

\begin{tabular}{lcc}
\hline \multicolumn{1}{c}{ Nutrisi } & Susu sapi & Whey keju \\
\hline Air (\%) & $84,0-89,5$ & 95,1 \\
Protein (\%) & $2,8-4,0$ & 0,85 \\
Lemak (\%) & $2,6-6,0$ & 0,27 \\
Laktosa (\%) & $4,5-5,2$ & 4,7 \\
Nilai pH & $6,3-6,8$ & 6,0 \\
\hline
\end{tabular}

\section{Kadar Alkohol}

Alkohol merupakan produk akhir dari proses fermentasi. Semakin tinggi konsentrasi starter maka akan menghasilkan asam laktat dan alkohol yang tinggi (Abubakar et al., 2000). Biji kefir merupakan gabungan dari bakteri BAL dan yeast yang bekerja secara sinergis. Laktosa pada whey akan dipecah oleh 
BAL menjadi asam laktat dan gula sederhana seperti glukosa, galaktosa sedangkan yeast akan memecah glukosa menjadi alkohol dan karbondioksida (Yuzriya dan Agustini, 2014). Kerjasama yang sinergis inilah yang menyebabkan whey kefir memiliki rasa asam dan juga berbau alkohol yang unik.

Perbedaan konsentrasi starter berpengaruh sangat nyata $(\mathrm{P}<0,01)$ terhadap kadar alkohol yang dihasilkan. Semakin tinggi konsentrasi starter yang ditambahkan maka semakin tinggi kadar alkohol yang dihasilkan. Kadar alkohol berkisar antara 1,63 sampai 1,98\%. Kadar alkohol tertinggi terdapat pada perlakuan whey dengan starter 9\% sedangkan kadar terendah pada kandungan starter 5\%. Yusriyah dan Agustini (2014) menyatakan bahwa susu sapi memiliki kandungan laktosa yang tinggi sehingga penambahan starter konsentrasi rendah mengakibatkan perombakan laktosa menjadi gula sederhana berlangsung lama dan perombakan gula menjadi alkohol menjadi lebih lambat. Kadar alkohol whey kefir disajikan pada Gambar 1.

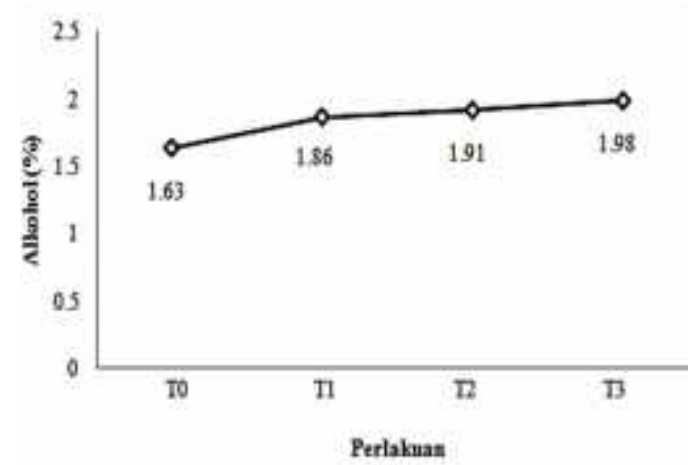

Gambar 1. Kadar alkohol whey kefir

Produksi alkohol dapat berlangsung selama proses pematangan dan penyimpanan pada suhu rendah. Suhu inkubasi yang rendah $\left(20^{\circ} \mathrm{C}\right)$ diduga menjadi salah satu alasan tinginya kadar alkohol yang dihasilkan (Stepaniak dan Fetlinski, 2002). Kefir yang diinkubasi pada suhu $24^{\circ} \mathrm{C}$ memiliki kadar alkohol 0,94\%, dengan demikian dapat diduga bahwa kefir yang diinkubasi dengan suhu lebih rendah dari $24^{\circ} \mathrm{C}$ akan memiliki kandungan alkohol yang tinggi (Purnomo dan Muslimin (2012).

\section{Nilai pH dan Total Asam Tertitrasi}

Proses fermentasi menghasilkan senyawa-senyawa metabolit berupa asam organik sehingga menyebabkan penurunan nilai pH produk fermentasi (Afriani, 2010). Nilai pH merupakan nilai yang menunjukkan derajat keasaman suatu bahan, dimana $\mathrm{pH}$ suatu produk fermentasi sangat berkaitan dengan kadar asam yang dihasilkan dan memiliki hubungan yang terbalik dengan nilai TAT. Semakin rendah nilai pH maka nilai TAT akan semakin tinggi (Adesokan et al., 2011).

Perbedaan konsentrasi starter berpengaruh sangat nyata $(\mathrm{P}<0,01)$ terhadap nilai pH yang dihasilkan. Perlakuan T1, T2, dan T3 tidak berbeda nyata satu sama lain namun ketiga perlakuan tersebut berbeda sangat nyata dengan perlakuan kontrol (T0) (Gambar 2).

Nilai pH whey kefir berkisar antara 3,59 sampai 3,60. Whey kefir memiliki nilai $\mathrm{pH}$ yang lebih rendah dibandingkan dengan whey segar sebelum difermentasi. Penurunan $\mathrm{pH}$ dipengaruhi oleh beberapa faktor diantaranya konsentrasi starter dan kandungan laktosa media fermentasi (Widodo, 2002). Nilai pH 
whey kefir tidak terlalu berbeda antar perlakuan karena konsentrasi starter yang digunakan juga tidak terlalu berbeda jumlahnya (Nihayah, 2014).

Nilai pH akan menurun seiring dengan tingginya laktosa pada whey. Hal ini terjadi karena mikroba mengubah laktosa menjadi asam organik sehingga mampu menurunkan nilai pH (El-mirza dan Mulyani, 2013). Peningkatan konsentasi starter berkaitan dengan peningkatan jumlah bakteri asam laktat yang menyebabkan penurunan $\mathrm{pH}$ (Hofvendahl et al., 2000; Lengkey et al., 2013). Nilai pH dan total asam tertitrasi whey kefir disajikan pada Gambar 2.

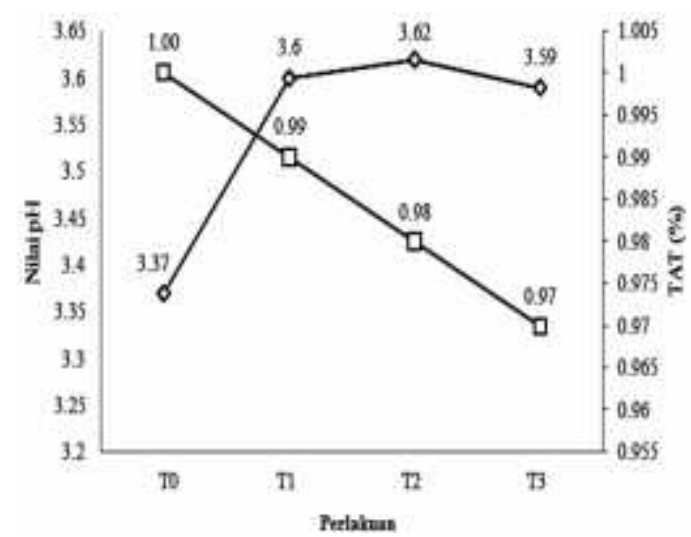

Gambar 2. Nilai pH dan TAT

Total asam tertitrasi merupakan jumlah asam laktat yang terbentuk selama proses fermentasi. Perbedaan konsentrasi starter berpengaruh sangat nyata $(\mathrm{P}<0,01)$ terhadap total asam tertitrasi. Perlakuan T0 (kontrol positif, starter 5\%) berbeda sangat nyata dengan nilai TAT yang lebih tinggi dari ketiga perlakuan lainya yaitu T1, T2, dan T3. Rosiana et al. (2013) menyatakan bahwa kadar asam produk fermentasi dipengaruhi oleh aktivitas bakteri yang merubah laktosa menjadi asam laktat. Semakin tinggi kadar laktosa maka total asam yang dihasilkan akan semakin tinggi.

Penurunan keasaman whey disebabkan oleh pertumbuhan mikroorganisme yang tidak terlalu baik akibat larutan asam yang dihasilkan. Penambahan konsentrasi starter yang semakin tinggi mengakibatkan laktosa yang dipecah oleh bakteri semakin banyak menjadi asam sehingga $\mathrm{pH}$ pada produk akan cepat menurun. Nilai $\mathrm{pH}$ yang rendah menyebabkan kultur terganggu sehingga berakibat pada turunnya produksi asam laktat (Maryana, 2014). Purbasari et al. (2014) juga menyatakan bahwa konsentrasi starter yang tinggi akan menghasilkan total asam tertitrasi yang menurun. Hal tersebut dikarenakan $\mathrm{pH}$ yang dihasilkan terlalu tinggi sehingga menghambat kinerja starter dalam merombak laktosa menjadi asam-asam organik. Seharusnya nilai minimal kadar TAT yaitu 0,6\%, namun dari keseluruhan hasil analisis kadar TAT whey kefir menunjukkan nilai lebih dari $0,6 \%$ sehingga tidak masuk standar minimal yang ditetapkan Codex (2003).

\section{KESIMPULAN DAN SARAN}

\section{Kesimpulan}

Semakin meningkat konsentrasi starter maka semakin tinggi kadar alkohol dan cenderung meningkatkan nilai total asam tertitrasi (TAT). 


\section{Saran}

Perlu dilakukan uji sensoris lebih lanjut untuk mengetahui derajat penerimaan konsumen terhadap produk whey kefir.

\section{UCAPAN TERIMA KASIH}

Ucapan terima kasih disampaikan kepada Politeknik Negeri Banyuwangi atas dana yang telah diberikan melalui hibah dana Penelitian Dosen Pemula (PDP) Internal 2017.

\section{DAFTAR PUSTAKA}

Abubakar, E. Dyah, H. Lengkey, dan D.S. Soetardjo. 2000. Kajian tentang dosis starter dan lama fermentasi terhadap mutu kefir. Seminar Nasional Peternakan dan Veteriner. Bogor.

Adesokan, I.A., B.B. Odetoyinbo, Y.A. Ekanola, R.E. Avanrenren, and S. Fakorede. 2011. Production of Nigerian nono using lactic starter cultures. Pakistan Journal Nutrition. 10(3): 203-207.

Afriani. 2010. Pengaruh penggunaan starter bakteri asam laktat Lactobacillus plantarum dan Lactobacillus fermentum terhadap total bakteri asam laktat, kadar asam dan nilai $\mathrm{pH}$ dadih susu sapi. Jurnal Ilmu-Ilmu Peternakan. 13 (6): 279-285.

Codex. 2003. Codex Standard for Fermented Milks: Codex STAN 243. FAO/WHO Food Standards (US): Codex Alimentarius Commission.

El-Mirza D.M. dan S. Mulyani. 2013. Produksi alkohol dari hasil samping pembuatan keju (whey) yang disubtitusi dengan limbah cair tapioka yang difermentasi oleh $S$. cerevisiae. Indonesian Food Technologi Community. 2(2): 80-86.

Farnworth, E.R. 2003. Handbook of Fermented Functional Foods. CRC Press. New York.

Guimaraes P.M.R., J.A. Teixeira, L. Domingues. 2010. Fermentation of lactose to bioethanol by yeast as part of intregated solution for the valorisation of cheese whey. Journal Elsevier. 28(1): 375-384.
Handayani, R.M. 2004. Pemanfaatan Whey untuk Produk Nata de Whey (Kajian Konsentrasi Starter dan Lama Inkubasi. Universitas Muhammadiyah Malang. Malang.

Hofvendahl, K. and B.H. Haegerdal. 2000. Factors affecting the fermentative lactic acid production from renewable resources. Enzyme and Microbial Technology. 26(1): 87-107.

Larasati, T, J. Kusnadi, dan E. Widyastuti. 2016. Pemanfaatan whey dalam pembuatan caspian sea yoghurt dengan menggunakan isolat Lactobacillus cremoris dan Acetobacter orientalis. Jurnal Pangan dan Agroindustri. 4(1): 201-210.

Laryska, N. dan T. Nurhajati. 2013. Peningkatan kadar lemak susu sapi perah dengan pemberian pakan konsentrat komersial dibandingkan dengan ampas tahu. Jurnal Agroveteriner. 1(2): 79-87.

Lengkey, H.A.W., J.A. Siwi, and R.L. Balia. 2013. The effect of various starter dosages on kefir quality. Lucrari Stiintiface Seria Zootehnie. 59(1): 113-117.

Londero, A., R. Quinta, A.G. Abraham, R. Sereno, G.D. Antoni, and G.L. Garrote. 2011. Inhibitory activity of cheese whey fermented whey with kefir grains. Journal of Food Protection. 74(1): 94100.

Maduiera, A.R., Pereira, A.M.P. Gomes, M.F. Pintado and Malcata.F.X. 2017. Bovine whey proteins overview on their main biological properties. Food Research International. 40(1): 1197-1211.

Maryana, D. 2014. Pengaruh Penambahan Sukrosa Terhadap Jumlah Bakteri dan Keasaman Whey Fermentasi dengan Kombinasi Lactobacillus plantarum dan Lactobacillus acidophilus. Skripsi. Universitas Hasanuddin. Makassar.

Nihayah, I. 2014. Pengaruh Konsentrasi Starter Terhadap Kualitas Kefir Susu Sapi dan Pemanfaatannya Sebagai Penurun Kadar Kolestrol Darah Mencit. Skripsi. Universitas Islam Negeri Maulana Malik Ibrahim. Malang.

Purbasari, A., H.D.R. Agustinus, dan S. Wasito. 2013. Pengaruh konsentrasi biji kefir dan waktu fermentasi terhadap viskositas dan penilaian organoleptik 
kefir susu kambing. Jurnal Ilmiah Peternakan. 1(3): 1021-1029.

Purnomo, H. and L.D. Muslimin. 2012. Chemical characteristic of pasteurised goat milk kefir prepared using different ammount of Indonesian kefir grains and incubation time. Food Research International. 19(1): 791-794.

Rosiana, E, Nurliana, and T.T.R. Armansyah. 2013. Lactic acid level and acidity of kefir goat milk fermented by various sugar addition and different time of incubation. Jurnal Medika Veterinaria. 7(2): 87-90.

Satria, A.V. dan Wildian. 2013. Rancang bangun alat ukur kadar alkohol pada cairan menggunakan sensor MQ-3 berbasir mikro kontroler Jurnal Fisika Universitas Andalas Padang. 2(1): 1319.

Standarisasi Badan Nasional. 2009. SNI 012981-2006 Yoghurt. Badan Standarisasi Nasional. Jakarta.

Stepaniak, L. and A. Fetlinski. 2002. Kefir, Encyclopedia of Dairy Science. Maryland. Academic Press. USA.

Usmiati, S. 2007. Kefir susu fermentasi dengan rasa menyegarkan. Warta Penelitian dan Pengembangan Pascapanen Pertanian. 29(2): 12-13.

Widodo. 2003. Bioteknologi Industri Susu. Lacticia Press. Yogyakarta.

Winarno, F.G. dan I.E. Fernandez. 2007. Susu dan produk fermentasinya. M-BRIO Press. Bogor.

Yusriyah, N.H., and R. Agustini. 2014. The effect of fermentation and concentration of kefir grains of quality of cow's milk kefir. Journal of Chemistry. 3(2): 15. 